\title{
An Empirical Study on Spiritual Formation at Protestant Theological Training Institutions in South Africa ${ }^{1}$
}

\author{
Marilyn Naidoo \\ Department of Practical Theology, University of South Africa, \\ P. O. Box 392, UNISA 0003, Republic of South Africa \\ naidom2@unisa.ac.za
}

\begin{abstract}
Spiritual formation is a significant component of the educational work of a theological institution that prepares students for church leadership. Theological institutions have a responsibility to engage students in reflecting on spiritual life, to provide opportunities for students to deepen their spiritual journeys and to develop in students a spiritual maturity that is required of future Christian leaders. This article reports on the findings of a descriptive study carried out with theological students during their training for Christian ministry. The aim of this research project was to conduct a comprehensive investigation into spiritual formation programmes to, firstly, find out whether spiritual formation is intentionally pursued, and secondly, to develop an instrument to measure the spiritual formation emphasis at theological institutions. As theological education in South Africa continues to assess its vision and goals, this exploratory study offers evidence to support the assumption that theological institutions are fulfilling their stated goals of shaping student spirituality.
\end{abstract}

\section{Keywords}

spiritual formation, theological education, church leadership, ministerial training

\section{Introduction}

Many theology institutions are again envisioning theological education as a formational activity; an activity based on the assumption that the student's personal appropriation of theology is the most central aspect of theological education. ${ }^{2}$ The most obvious reason for this is the preparation and shaping of

1 This research was supported by grants from the National Research Foundation and is gratefully acknowledged.

${ }^{2}$ Martin Percy, Shaping the Church: The Promise of Implicit Theology (Burlington: Ashgate, 2010), 131. 
future church leaders: theological students need to become aware that ministry in the form of ministerial leadership is a public and not a private role. Students must therefore be attuned to the issues of behaviour and accountability required of those who enjoy the community's trust. There will thus be particular demands upon the leader's spirituality. ${ }^{3}$ As teachers of the tradition, leaders are expected to know what they are speaking about, and this demands some sort of internalisation of the tradition and competence in living out of its resources. ${ }^{4}$ If they are to provide leadership to congregations and individuals under all sorts of conditions, they must understand human behaviour in health and adversity. This requires some degree of psychological, anthropological and sociological understanding, as well as a theological grasp of the human condition before God. ${ }^{5}$ It requires insight and penetration and a multitude of other personal qualities which rest upon one's self-knowledge and on the character of one's spiritual life.

It is essential to note the formation of ministerial identity in the conceptualisation of spiritual formation. ${ }^{6}$ Because a certain type of person is needed to be trained for church leadership with a particular spiritual aptitude or maturity, theological institutions need to take responsibility and become more deliberate in this mandate. However, over the last few decades there has been much debate on the nature and place of spiritual formation in theological institutions. ${ }^{7}$ The largest body of literature available comes from the growing dissatisfaction with theological education from the 1970s onwards expressed by churches and increasingly the educators themselves. ${ }^{8}$ This has resulted in a

${ }^{3}$ Phillip Hill, "The Person of the Pastor: A Primer for Pastoral Effectiveness," Dissertation Abstracts International 63, no. 3 (2002): 992.

${ }^{4}$ Howard Rice, The Pastor as Spiritual Guide (Nashville: Upper Room, 1998), 34-5.

${ }^{5}$ Johannes van der Ven, Education for Reflective Ministry (Louvain: Peeters, 1998), 171.

${ }^{6}$ Gregory Jones and Kevin Armstrong, Resurrecting Excellence: Shaping Faithful Christian Ministry (Grand Rapids: Eerdmans, 2006); Joretta Marshall, "Formative Practices: Intent, Structure, and Content," Reflective Practice: Formation and Supervision in Ministry 29 (2009): 56-72.

7 George Lindbeck, Charles Wood and Tilden Edwards, "Spiritual Formation in Theological Schools: Ferment and Challenge," Theological Education 17, no. 1 (1980):10-32; Walter Liefeld and Linda Cannell, "Spiritual Formation and Theological Education," in Alive to God: Studies in Spirituality (ed. J. Packer, L. Wilkinson and J. Houston; Downers Grove: InterVarsity, 1992), 239-52.

${ }^{8}$ Through the early 1970s and into the 1980s, various conferences were convened to study spiritual formation: David Babin et al., Voyage, Vision, Venture: A Report (Dayton: American Association of Theological Schools, 1972); Tilden Edwards, "Spiritual Formation in Theological Schools: Ferment and Challenge," Theological Education 17, no. 1 (1980): 4-10; Samuel Amirtham, Spiritual Formation in Theological Education: An Invitation to Participate: Programme On Theological Education (Geneva: World Council of Churches, 1987); see Liefeld and Cannell, "Spiritual Formation and Theological Education," 239-52, for a discussion on the various studies done in Protestant seminaries in the United States. 
new search for a greater emphasis on the spiritual formation of the student. This interest in the subject is traceable in the Association of Theological Schools (ATS) North American seminary movement, the Roman Catholic Church, The World Council of Churches affiliated colleges across the world and the Evangelical Accrediting Movement. Many of these reports and conference papers can be read in various editions of the journal Theological Education. Much of the literature on the subject of spiritual formation has to do with defining terminology and discussing the wisdom of trying to solve the problem at all.

\section{Spiritual Formation in Theological Education}

The term "formation" has a range of meanings in different contexts. The Roman Catholic tradition has a sacramental conception of ministry as priesthood. Formation takes place through the provision of programmes and resources organised around clear institutional goals. A good outline of the history can be found in John O'Malley's article "Spiritual Formation for Ministry; Some Roman Catholic Traditions - their Past and Present." The most recent document is the apostolic exhortation of 1992 Pastores Dabo Vobis which highlights the priest's fundamental relationship to Jesus Christ and with the Church. The exhortation affirms that the mission of the seminary embraces four key dimensions of formation: human, intellectual, spiritual and pastoral. The fourth edition of the Program of Priestly Formation ${ }^{10}$ highlighted the need for a new emphasis on priestly identity with the insistence that the priesthood is unique in the Church and therefore ought to have its own specialised programmes of learning and formation. ${ }^{11}$

Within Protestant theological education, a major consideration in determining the goal and content of formation is to honour the expectations that the Church has of its leaders. At the end of the formation period, educators should be confident that they are recommending worthy candidates for ordination or church ministry. The expression of the three major dimensions of formation may be summarised as a cognitive or intellectual apprenticeship, a

\footnotetext{
9 John O’ Malley, "Spiritual Formation for Ministry: Some Roman Catholic Traditions Their Past and Present," in Theological Education and Moral Formation (ed. R. Neuhaus; Grand Rapids: Eerdmans, 1992), 20-30.

${ }^{10}$ National Conference of Catholic Bishops, Program of Priestly Formation (4th ed.; Washington, D.C.: United States Catholic Conference, 1993).

${ }^{11}$ Katrina Schuth, Seminaries, Theologates, and the Future of Church Ministry (Collegeville: Liturgical Press, 1999), 29.
} 
practical apprenticeship of skill and an apprenticeship of character or spiritual formation. ${ }^{12}$ This last aspect of ministerial formation is the focus of this research. Spiritual formation encompasses a wide range of competencies and traits. It includes "conversion of mind and heart, fostering integrative thinking, character formation, promoting authentic discipleship, personal appropriation of faith and knowledge, and cultivating a spirituality of the intellectual life."13 It must be noted that people are constantly in a process of formation, in families, in congregations, in faith traditions and through society at large, but the focus here is limited to a theological formation, the "spiritual shaping" of students over a period of time spent at a theological institution.

Effective integration of the above three aspects of ministerial formation has seldom been achieved in the Protestant theological institution. ${ }^{14}$ Instead what one finds in theological institutions is that the educational programme favours academic instruction with some practical exposures and compartmentalises the spiritual, with spiritual formation happening implicitly, informally and on a personal basis. The common academic pattern, drawn from the university model, continues to be departmentalised with further specialisation within those departments. The reason for the fragmentation and isolation of disciplines has been a subject of concern in the literature for several years. ${ }^{15}$ The scholastic method further shaped by the Enlightenment has resulted in the study of theology becoming a science supporting the professionalisation of the ministry. ${ }^{16}$ Farley attributed this situation to the fragmentation of a formerly unified theology. ${ }^{17}$ Theology has diversified into practical ministry skills and an aggregate of disciplines which emphasises the cognitive over the spiritual. $^{18}$

\footnotetext{
12 Allan Harkness, "De-Schooling the Theological Seminary: An Appropriate Paradigm for Effective Ministerial Formation," Teaching Theology and Religion 4, no. 3 (2001): 141-154.

13 Patricia Lamoureux, "An Integrated Approach to Theological Education," Theological Education 36, no. 1 (1999): 141-56.

14 Edward Farley, Theologia: The Fragmentation and Unity of Theological Education (Philadelphia: Fortress, 1983); Charles Wood, Vision and Discernment: An Orientation in Theological Study (Atlanta: Scholars Press, 1985); David Kelsey, Between Athens and Berlin: The Theological Education Debate (Grand Rapids: Eerdmans, 1993).

15 Charles Wood, "Vision and Discernment: An Orientation in Theological Study," in Christian Identity and Theological Education (ed. J. Hough and J. Cobb; Atlanta: Scholars Press, 1985); Kelsey, Between Athens and Berlin, 23.

${ }^{16}$ Linda Cannell, Theological Education Matters - Leadership Education for the Church (Newburgh: Edcot, 2006), 36.

17 Farley, Theologia, 42.

18 Max Stackhouse, Apologia: Contextualisation, Globalisation and Mission in Theological Education (Grand Rapids: Eerdmans, 1988), 36; Robert Banks, Revisioning Theological Education: Exploring a Missional Alternative to Current Models (Grand Rapids: Eerdmans, 1999).
} 
In the average Protestant theological institution, spiritual formation is now becoming an important area of the mandate, but how to meet that need is still a matter of debate. ${ }^{19}$ Disputed issues include the theological and educational status of the field of spiritual formation and the relationship between spiritual formation and other aspects of ministerial education..$^{20}$

\section{The Research Project}

This research was based on the hypothesis that Christian spiritual formation is central to the educational work of the theological institution. It is important for Christian spiritual formation to be intentional; i.e., it needs to be carefully thought out, understood and deliberate strategies need to be developed to promote it. ${ }^{21}$ In this way, theological educators can ensure that theological students leaving their institution after a period of study have actually progressed in terms of their understanding and experience of God, and that students have the ability to live out, both in terms of personal character and their ministries, a deep consciousness of the love of God.

While there is little disagreement about the significance of the elements involved in preparing church leaders, ${ }^{22}$ there is no corresponding unanimity regarding how spiritual formation formally fits into a theological institution's culture - whether spiritual formation is primarily about personal spirituality and only secondarily related to academic study and pastoral training, or whether students perceive theological institutions to have a positive influence on their spirituality. This kind of discussion is hard to come by in South Africa $^{23}$ together with the fact that reports are obscure and limited to denominational church minutes and documents, hence the reason for this research.

19 Cannell, Theological Education Matters, 35-43

${ }_{20}$ Tilden Edwards, "Spiritual Formation in Theological Schools," 4; Banks, Revisioning Theological Education; Gregory Jones, "Beliefs, Desires, Practices and the End of Theological Education," in Practicing Theology: Beliefs and Practices in Christian life (ed. M. Volf and D. Bass; Grand Rapids: Eerdmans, 2002), 56.

${ }^{21}$ Charles Foster, Lisa Dahill, Larry Golemon and Barbara Tolentino, Educating Clergy: Teaching Practices and Pastoral Imaginations (San Francisco: Jossey-Bass, 2006), 101; Joretta Marshall, "Formative Practices: Intent, Structure, and Content," Reflective Practice: Formation and Supervision in Ministry 29 (2009): 65.

${ }^{22}$ Roger Finke and Kevin Dougherty, "The Effects of Professional Training: The Social and Religious Capital Acquired in Seminaries," Journal for the Scientific Study of Religion 41, no. 1 (2002): 103-20.

${ }^{23}$ Marilyn Naidoo, "The Call for Spiritual Formation in Protestant Theological Institutions in South Africa," in The Spirit that Empowers: Perspectives on Spirituality (eds. P. G. R. de Villiers, C. E. T. Kourie and C. Lombaard; Acta Theologica Supplementum 11, 2008), 129-42. 
The aim of this research project was to conduct an exploratory investigation into spiritual formation programmes at selected Protestant theological institutions in South Africa to (1) find out whether spiritual formation is being intentionally pursued, (2) to examine the academic and non-academic methods in which spiritual formation is being fostered in theological institutions, and (3) to develop a valid and reliable instrument to measure the spiritual formation emphasis at theological institutions. For this article only aim (1) and (3) will be reported on.

\subsection{Theoretical Framework}

Many definitions of spiritual formation abound from a review of the literature, but one that is helpful to this discussion comes from a World Council of Churches publication where spiritual formation is defined as "the intentional processes by which the marks of an authentic Christian spirituality are formed and integrated." ${ }^{24}$ In this definition certain processes are discussed that allude to the processes of spiritual development, and for Christian spirituality to be authentic, it must be integrated into the lives of the students and so be observable, whether that be in the classroom, church or society. Spiritual formation is not simply developing the "spiritual" aspect of a theological student, but has to do with the integration of the intellectual, psychological, social, cultural and spiritual dimensions of life in the educational process. ${ }^{25}$ "Methods" for spiritual formation are not methodological in the sense that they "produce" the type of spirituality one desires or effectively guarantee certain "results" which afterward can be measured like intellectual abilities. Rather, taking into account the fact that each person already has a certain kind of spirituality, different methods of spiritual formation are conceived as helping each person to discover and be transformed to manifest the marks of true Christian spirituality. If a variety of means are not found through which spiritual formation of students can deliberately be pursued, it may not take place at all.

Ballard and Pritchard offer four "models of practical theology" which include the applied theory, critical correlation, praxis and habitus model. ${ }^{26}$ While all four models are used in the Church, the model of critical correlation

\footnotetext{
${ }^{24}$ Samuel Amirtham and Robin P. Pryor, eds., Resources for Spiritual Formation in Theological Education (Geneva: World Council of Churches, 1989), 17.

${ }_{25}$ Malcolm Warford, ed., Practical Wisdom: On Theological Teaching and Learning (New York: Lang, 2007), 36.

${ }^{26}$ Paul Ballard and John Pritchard, Practical Theology in Action: Christian Thinking in the Service of Church and Society (London: SPCK, 1996) note their indebtedness for this to Farley, Theologia, 57-70.
} 
represents the focus of how academia tends to engage with theology, bringing methods of a wide range of disciplines of enquiry into dialogue with theology and ecclesial practice. For this research, the concept of ministerial and spiritual formation is embedded in the habitus model in which the theological institution, as a distinctive and historical community, fosters values through corporate worship and shared discipleship, forming a "disposition of the heart" of students. ${ }^{27}$ Theology here has a particular meaning, which is not intended to be based on dogmatic method. In the habitus model we see an ecclesiological understanding of formation concerning more than the object of study: it is a model of learning in which faith, study and tradition inform one another, and thereby foster the development of the person. This formational notion of theological education is what Farley labels as theologia, the unity and goal of which is the saving knowledge of God. ${ }^{28}$ In this approach the teacher shares his or her struggles to attain appropriate wisdom with the student. The most meaningful experiences for students are focused on the teacher's relational skills and personal qualities, and in-class interactive teaching and learning methods. ${ }^{29}$ For students, developing community and relationships within an academic setting is not only important, but also necessary in facilitating learning. The goal is to help the student undergo a deep kind of formation - a personal appropriation of wisdom about God, the self and the world where learning is not just a personal matter but is done for the sake of public life, ecclesial life and Church leadership. This is in line with what Groome refers to as reflective practitioners: ${ }^{30}$ "they should be invited to discern and express their own critical understanding of both praxis and theory and be sponsored through judgment and decision to see for themselves and responsibly choose what is appropriation to lived Christian faith." 31

Several concepts were selected from the literature that would make for a spiritual formation emphasis at an education institutional. First, it would involve intentionality towards spiritual development evidenced in the life of

${ }^{27}$ Farley, Theologia, 69.

${ }^{28}$ Farley, Theologia, 36-7.

29 Foster et al., Educating Clergy, 168.

30 The reflective judgement literature and those concerned about praxis assert that theological education is a reflection on the practice of ministry while one is involved in that ministry. The assumption of a theory-to-practice linearity is replaced with the assumption that practice can also influence theory - see Cannell, Theological Education Matters, 36.

31 Thomas Groome, “A religious educator's response," in The Education of the Practical Theologian: Response to Joseph Hough and John Cobb's Christian Identity and Theological Education (ed. D. S. Browning, D. Polk and I. S. Evison; Atlanta: Scholars Press, 1989), 77-91. 
the community and within a curriculum that is holistic and integrative. ${ }^{32} \mathrm{An}$ institution that makes a corporate decision to do so should apply resources to the goal. A critical influence in formation is the involvement of the staff as they model integrity to the students. ${ }^{33}$ Spiritual formation within the academic setting is most effective when the classroom is both affirmed and complemented. Hence both formal and informal learning of spirituality is embedded in the context of shared lives. Research also supports the value of relationship as a learning tool, ${ }^{34}$ and community life can multiply learning opportunities. ${ }^{35}$ Other services like counselling, progressive assessments and mentorships, etc. that specifically focus on spiritual development could be made available to students. Theological institutions should be a worshipping community evidenced by various devotional activities. ${ }^{36}$ These concepts are the essential requirements that go into a spiritual formation programme, although within denominational theological institutions there could be other theological distinctives, practices and rituals that influence spiritual formation. For example, different traditions will identify with different schools of spirituality: ${ }^{37}$ speculative/kataphatic - head spirituality, primarily a "thinking" approach; affective/kataphatic - a heart spirituality, drawing on a charismatic, affective way of connecting with God; affective/apophatic - a mystic spirituality, more interested in being with God than expressing oneself to God, and speculative/apophatic - a kingdom spirituality that is committed to witnessing to God in the world.

\subsection{Method}

This was a descriptive study using a mixed-methods approach using semistructured interviews and a student questionnaire. The mixed-method model used was concurrent triangulation where both methods are given equal

${ }^{32}$ Les L. Steele, On the Way: A Practical Theology on Spiritual Formation (Grand Rapids: Baker, 1990); Marshall, Formative Practices, 58.

33 Mercer Merv, "Formational Initiatives at Wycliffe College," Theological Education 39, no. 2 (2003): 53-63; Laurent Daloz, Mentor: Guiding the Journey of Adult Learners (San Francisco: Jossey-Bass, 1999).

${ }^{34}$ Alexander Astin, What Matters in College: Four Critical Years Revisited (San Francisco: Jossey-Bass, 1993); Lamoureux, An Integrated Approach to Theological Education.

${ }^{35}$ James Poling and Donald Miller, Foundations for a Practical Theology of Ministry (Nashville: Abingdon, 1985); Kathy Mills, “The Culture of the Christian School,"Journal of Education and Christian Belief 7, no. 2 (2003): 129-42.

${ }^{36}$ Gregory Jones, "Beliefs, Desires, Practices and the End of Theological Education," 62.

37 Corrine Ware, Discover Your Spiritual Type: A Guide to Individual and Congregational Growth (Bethesda: Alban Institute, 1995). 
emphasis and combined in the interpretation phase, which promotes the triangulation of data. ${ }^{38}$ The study used a cross-sectional research design where observations were made at one point in time in seven different Christian campuses. All fieldwork and data collection at each site was conducted by a single trained fieldworker who, in most cases, was a lecturer or spiritual caregiver involved in student formation. This added many perspectives, backgrounds and social characteristics and yielded a more complete picture of spiritual formation at theological institutions.

Data was collected from students at theological institutions to test their perceptions of the spiritual formation emphasis at their institution. To do this, a student questionnaire was designed which also contained a spiritual formation index or scale. This attends to the first and third aim of the project. A two-stage stratified sample was used for data collection. The second data analysis produced the final form of the Spiritual Formation Index. Descriptive and inferential statistics were used for the final reporting on students' perceptions on the formational emphasis at theological institutions.

Data was also collected qualitatively through semi-structured interviews with the management or principals of theological institutions to gauge the institution's responsibility to students' spiritual formation and the intentionality of it within the curriculum and institution. In addition, fieldworkers collected data through observations of various spiritual formational activities on campuses, through an analysis of the curriculum to establish the priority of spiritual formation and through the collection of institutional documents. This attends to the second aim of the project, not reported on in this article due to space. A descriptive matrix data analysis methodology was used in comparing, conceptualising and categorising qualitative data. ${ }^{39}$ A conceptual map was designed placing theological institutions on a spectrum based on the intentionality of spiritual formation at their institution. The results of this qualitative and quantitative study were then integrated in the interpretation of results. Triangulation was used to measure a spiritual formation emphasis in more than one way and enable the researcher to see all aspects of it. This integrative process enabled the answering of the research question depicting the overall intentionality of the institutions' priority of spiritual formation.

${ }^{38}$ John Cresswell, Vicki Clark, Michelle Gutmann and William Hanson, "An Expanded Typology for Classifying Mixed Methods Research into Designs," in The Mixed Methods Reader (ed. V. Clark and J. Cresswell; Thousand Oaks: Sage, 2008), 159-96.

${ }^{39}$ Anselm Strauss and Juliet Corbin, Basics of Qualitative Research (Newbury Park: Sage, 1990), 61. 


\subsection{Sample}

The sample with which an instrument is tested needs to be narrow enough for participants to share a similar understanding of spiritual formation, yet broad enough so that the data collection will not be biased by a single denomination's particular emphasis in doctrine or lifestyle. For this reason, a representative sample was selected made up of different church traditions, cultures and language groups of Protestantism in South Africa. The sample included seven theological institutions: Baptist Convention College, Seth Mokitimi Methodist Seminary, College of Transfiguration (Anglicans), University of the Free State (Reformed), Cape Theological Seminary (Pentecostal), Hatfield Training Centre (Charismatic) and University of Pretoria (Presbyterian). The selection criteria were based on the availability of an on-site field worker, education and training for church leadership, an accredited theological programme with the Department of Education, and teaching and learning that involved contact teaching sessions. Inter-denominational and distance education theological institutions were considered unsuitable for the sample because of the unsuitability of the dynamics of ecumenical formation ${ }^{40}$ and, in the case of distance education, because of a lack of real-time interaction, modelling of faculty and the absence of community life.

These selected theological institutions have approximately 300 students as total registration per year. Since theological institutions have different student registration figures, stratified sampling of students was used so as to be able to legitimately generalise information from a few people. An average of 40 fulltime students from different years of study was surveyed from each institution. Study participants consisted of a stratified sample of 280 students $(n=280)$ enrolled full-time for the graduate-level courses in a denominational theological institution with a response rate of $93 \%$. The sample was made up of students from Methodist 39 (14\%), Anglican 46 (17\%), Baptist 25 (9\%), Reformed 52 (19\%), Pentecostal 40 (15\%), Presbyterian 22 (8\%) and Charismatic $45(17 \%)$. A total of 101 (36\%) participants were White, $146(52 \%)$ were African, 27 (9\%) were Coloured and 2 (1\%) were Indian, 246 (88\%) were South African citizens and $33(11 \%)$ were students from other countries. Included in the sample were 109 (40\%) females and 166 (60\%) males. Students were enrolled in different years of study: 89 (32\%) were first-year students, $100(36 \%)$ were second-year students and 88 (30\%) were final-year students.

\footnotetext{
${ }^{40}$ John Lindner, "Ecumenical Formation: A Methodology for a Pluralistic Age," Theological Education 34 (1997): 7-14.
} 
The majority of 192 students (72\%) were training for the ordained ministry, while 75 (28\%) were training for the lay ministry. The highest educational qualification of students showed that 177 (64\%) had completed secondary schooling, while $98(35 \%)$ had a previous qualification before entering theological training. The majority of students (55\%) were between 18 and 28 years old, with the average age of respondents being 29 years.

\subsection{Student Questionnaire}

Because the main focus is on the spiritual formation among theological students, a questionnaire was designed to get more data on the profile of the theological student, their spirituality practices and habits, their stressors during their theological training and how they perceive spiritual formation within their institutions. In valuing student perceptions on spirituality, respect is shown to their personhood and their right and responsibility to make their own meaning. Failure to accommodate student understandings might result in "power over" violations in the formation process.

A lengthy questionnaire was formulated from the literature and from ATS (Profiles of Ministry) inventories for use with seminary students and young ministers. ${ }^{41}$ From the first data collection it was evident that there was a general apathy from students in completing the questionnaire. A reason for this could be the lengthy questionnaire and that many of the questions seemed similar and repetitive for students. To get a quality response for the second data collection, questions were generally rephrased, added or simplified and the questionnaire was reduced from 30 to 21 questions. The structure of the questionnaire involved twelve questions (quantitative control variables) covering biographical data which included questions on the profile of students: gender, age, race, denomination, registration information, etc. Seven questions (mostly layered scale questions) were on students' personal spirituality and spirituality within the institution. One question involved the spiritual formation index (made up of 34 items on a five-point Likert scale-interval) that looked specifically at different aspects of the formation process within the institution.

\subsection{Design and Development of the Spiritual Formation Index (SFI)}

The spiritual formation index ${ }^{42}$ is designed to test students' perceptions of the spiritual formation emphasis at their theological institution. It measures

${ }^{41}$ Daniel Aleshire, "ATS Profiles of Ministry Project," in Clergy Assessment and Career Development (ed. R. Hunt, J. Hinkle and N. Malony; Nashville: Abingdon, 1990), 97-103.

${ }^{42}$ A scale consists of "effect indicators" - i.e., items whose values are caused by an underlying 
involvement in formational activities offered by the theological institution. It does not purport to assign a level of achievement or maturity to the student's involvement. Measurement instruments are collections of items combined into a composite score. This is an unweighted factor-based scale ${ }^{43}$ where respondents' raw scores on each item are added to obtain an average (mean) which is the scale score. Total possible scores range from 1 to 5 (five-point Likert scale $1=\mathrm{SA}$ to $5=\mathrm{SD}$ ) with lower scores reflecting a stronger sense of spiritual formation.

There are a number of different measures developed to access spirituality and religiosity, ${ }^{44}$ however they are focused in the dominant framework in psychology of religion: instrinsic and extrinsic religious orientation. ${ }^{45}$ Other instruments consider frameworks for studying religious motivation, belief and behaviour by using the attachment theory. ${ }^{46}$ Many measures for spirituality exist but no established instrument appears to be suitable for measuring the perceived formational emphasis within a theological institution, hence a new instrument was developed. Items were generated from the review of the literature and existing scales and qualitative studies ${ }^{47}$ on spiritual formation. Six key concepts that include the idea of process and integration were used: (1) institutional commitment towards spiritual formation, (2) specialised services offered by the institution, (3) formal/informal learning of spirituality, (4) community life, (5) staff/faculty involvement in spiritual formation, and (6) spiritual activities on campus.

Initially a complex student index was designed with seven theoretical concepts (formal and informal learning were two different concepts) and an initial pool of 28 items on a five-point Likert-scale interval. The first data collection was administered to 200 second- and third-year students who were exposed to

construct (Kenneth Bollen, Structural Equations with Latent Variables (New York: Wiley, 1989), for example in a measure of depression. An index is used to describe sets of items that are "cause indicators", i.e., items that determine the level of a construct (Robert DeVellis, Scale Development: Theory and Applications (London: Sage, 2003). A measure of a formational programme fits the characteristics of an index - the services offered, alignment of programme and the use of resources. Although these items do not share a common cause, they all share an effect - an educational programme. The items are not a result of any one thing but they determine the same outcome.

43 David de Vaus, Surveys in Social Research (London: ULC, 1991), 266.

${ }_{44}$ Peter Hill and Ralph Hood, eds., Measures of Religiosity (Birmingham, Ala.: Religious Education, 1999).

45 Kenneth Pargament, "Of Means and Ends: Religion and the Search for Significance," International Journal for the Psychology of Religion 9, no. 1 (1992): 3-16.

46 Richard Gorsuch, "Measurement in Psychology of Religion Revisited," Journal of Psychology and Christianity 9, no. 2 (1990): 82-92.

47 Marilyn Naidoo, “An investigation into Spiritual Formation Programmes at selected Evangelical institutions in Kwa-Zulu Natal” ( D.Th. diss., University of Zululand, 2005). 
formational activities. A pilot data analysis was conducted to test the reliability and validity of the index. The goal was also to reduce the number of items in the index and to test the data for consistency in terms of the theoretical dimensions. To assist in determining which items to place in each scale dimension, factor analysis using the principal components method with varimax rotation was used. Six factors were found that were developed into six theoretical dimensions after initially having seven theoretical dimensions. The index was adjusted from 28 items to 34 items with six dimensions with an average of five questions within each dimension. The second data collection was conducted among 280 first-, second- and third-year students after a year of exposure to formational activities at the various institutions. The data was analysed using the SAS JMP statistical package using frequencies, cross-tabulations, factor analysis, and reliability and correlation routines. In its final form, the index was reduced to 31 questions eliminating three items (see Appendix A for the list of items in each dimension).

\subsection{Reliability and validity of SFI}

A factor analysis was performed to determine if the individual questions contributed to the dimensions as in the scale. The KMO Bartlett value was 0.936 with a significant value and shows that this set of variables in a correlation matrix was suitable for factor analysis. Exploratory factor analysis was done and six factors were found with Eigen values of more than 1, the cumulative percentage explained by the factors is more than $60 \%$ and a significant decline in scree plot.

To identify clusters of items that had consistent and coherent content, factor rotation was done (see Table 1 in Appendix B). Ideally rotation will result in factors on which only some variables load and variables that load on only one factor. ${ }^{48}$ Varimax rotation was used to show that all individual questions loaded exactly onto the six factors as expected except for the three questions $131 \mathrm{G}, 132 \mathrm{~F}$ and 136A. 131G belonged to Factor 1 and loaded onto Factor 5 as $0.46 .132 \mathrm{~F}$ was part of Factor 5 and loaded on to Factor 1 with a loading of 0.35 . 136A was part of Factor 6 but loaded with Factor 4 with a loading of 0.49 . Factor analysis was repeated on the index after the removal of the three questions (to support content validity) and six factors were found with Eigen values of more than 1; cumulative percentage of variance explained improved from $62 \%$ to $64 \%$ and there was a significant decline in scree plot.

\footnotetext{
${ }_{48}$ Andrew Comrey, "Common Methodological Problems in Factor Analytic Studies," Journal of Consulting and Clinical Psychology 46 (1978): 648-59.
} 
In factor analysis, restricting the number of factors to the number of dimensions and comparing the obtained factors with the proposed factors is a method used to test the scales empirically. ${ }^{49}$ When varimax rotations of factor analysis were used, a six-factor solution was carried out with the items of the spiritual formation index's final form, and all of the obtained groupings of variables corresponded to the proposed factors. The six factors that go together are (1) institutional commitment towards spiritual formation, (2) specialised services offered by the institution, (3) formal/informal learning of spirituality, (4) community life, (5) staff/faculty involvement in spiritual formation, and (6) spiritual activities at campus. These factors tie in with the theoretical concepts found in the literature that makes for spiritual formation.

To test for reliability item analyses was conducted to produce Cronbach alpha values on each dimension of the index. The Cronbach alpha values were generally high with the coefficient alpha for (1) institutional commitment being .8382 , for (2) services offered being .8241, for (3) formal/informal learning being .8558 , for (4) community life being .8026 , for (5) staff/faculty involvement being .8911, and for (6) spiritual activities at campus being .7626.

\subsection{Results}

(i) Overall Profiling of Theological Institutions According to the SFI

Table 2 shows the difference between theological institutions in terms of how they subscribed to the different dimensions of the SFI. To calculate this, the average student response for each factor for each institution was calculated to show the following scores:

Table 2. Institutional profiling according to factors

\begin{tabular}{lcccccc}
\hline $\begin{array}{l}\text { Theological } \\
\text { Institution }\end{array}$ & $\begin{array}{c}\text { Institutional } \\
\text { commitment: } \\
\text { Factor 1 }\end{array}$ & $\begin{array}{c}\text { Services } \\
\text { offered: } \\
\text { Factor 2 }\end{array}$ & $\begin{array}{c}\text { F/Informal } \\
\text { learning: } \\
\text { Factor 3 }\end{array}$ & $\begin{array}{c}\text { Community } \\
\text { life: } \\
\text { Factor 4 }\end{array}$ & $\begin{array}{c}\text { Staff involve: } \\
\text { Factor 5 }\end{array}$ & $\begin{array}{c}\text { Spiritual } \\
\text { activities: } \\
\text { Factor 6 }\end{array}$ \\
\hline Anglican & 1.90 & 2.43 & 1.88 & 1.90 & 2.01 & 2.08 \\
Baptist & 1.76 & 2.69 & 2.02 & 1.81 & 1.78 & 2.13 \\
Charismatic & 1.29 & 1.92 & 1.58 & 1.68 & 1.42 & 1.97 \\
Methodist & 2.05 & 3.11 & 2.34 & 2.41 & 2.52 & 2.88 \\
Pentecostal & 1.61 & 2.33 & 1.75 & 1.77 & 1.79 & 2.07 \\
Presbyterian & 2.33 & 2.66 & 2.40 & 2.56 & 2.37 & 2.77 \\
Reformed & 2.39 & 2.37 & 2.49 & 2.47 & 2.26 & 2.88 \\
\hline
\end{tabular}

49 David De Vaus, Surveys in Social Research, 265. 


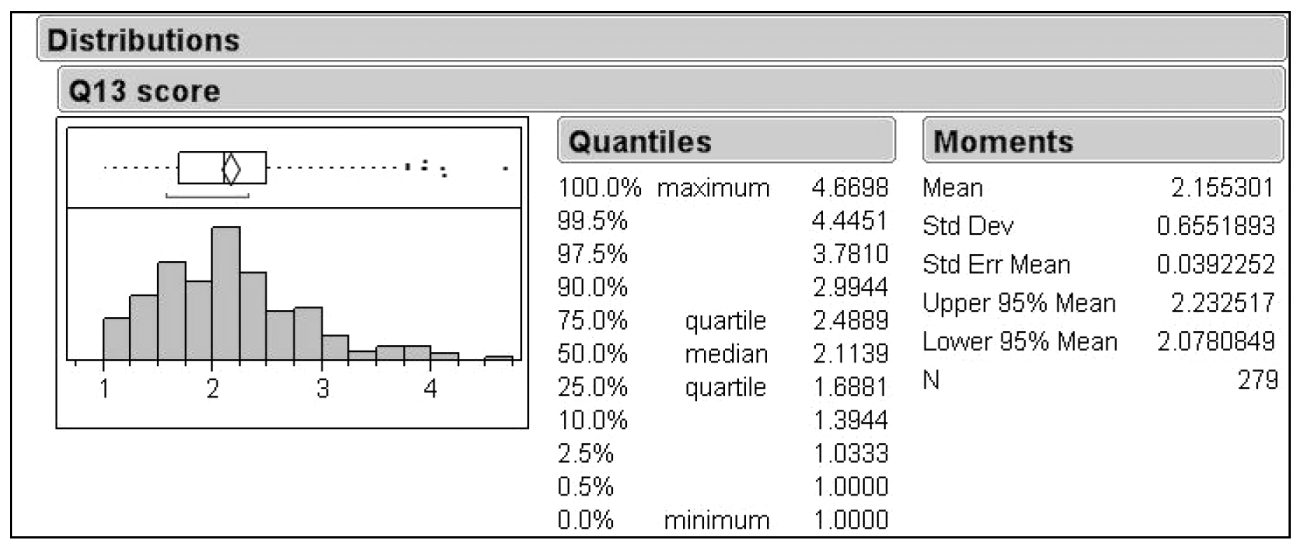

Figure 1: Histogram of the overall SFI

To calculate the overall mean score for each institution, the average of all factors was calculated. The overall mean score for the spiritual formation index was 2.16 , with $n=269$ (see Figure 1). These mean scores measured the extent to which institutions subscribe to the overall spiritual formation index with a lower mean score indicating more agreement with spiritual formation $(1=$ SA... $5=\mathrm{SD})$. The mean scores for each institution can be seen in Figure 2.

From the histogram in Figure 1 it can seen that the data is skewedly distributed to the right. $75 \%$ is below the value 2.49 which are students that agree or strongly agree with the spiritual formation index. The overall SFI is not normally distributed, therefore the Krauskal-Wallis sign rank test is used to test for differences between the ranks among the seven institutions. This technique tells us whether the differences between the observed sample ranks are likely to exist in the population from which the sample was drawn. The analysis revealed a significant difference between the ranks among the seven institutions $\left(\chi_{6}^{2} \approx 78.85 ; \mathrm{p}<0.001\right)$. The $\mathrm{p}$-value is smaller than .01 which shows a significant difference between the ranks of the institutions at a $99 \%$ level of confidence.

In Table 3 significant differences can be seen in the means between the different institutions. For example, there are slight or not significant differences between the groups Methodist, Reformed and Presbyterian, but as a group they have significant differences to the group Anglican, Baptist and Pentecostal. The Pentecostal could also fall into the Charismatic group and this group is significantly different from the other two groups. 
Table 3. Non-parametric comparisons for each pair using the Wilcoxon method

\begin{tabular}{|c|c|c|c|c|}
\hline Level & & & & Mean $^{50}$ \\
\hline Methodist & A & & & 2.5304843 \\
\hline Presbyterian & A & & & 2.5165584 \\
\hline Reformed & A & & & 2.4792659 \\
\hline Anglican & & B & & 2.0355159 \\
\hline Baptist & & B & & 2.0333492 \\
\hline Pentecostal & & B & $\mathrm{C}$ & 1.8862897 \\
\hline Charismatic & & & $\mathrm{C}$ & 1.6458642 \\
\hline
\end{tabular}

Levels not connected by same letter are significantly different.

Table 4. Students rating on different priorities within institutions

\begin{tabular}{lccccc}
\hline Institution & Skills & Tradition & Knowledge & Spirituality & Context \\
\hline Methodist & 3.32 & 3.15 & 3.37 & 3.34 & 3.68 \\
Anglican & 3.42 & 3.42 & 3.73 & 3.5 & 3.42 \\
Baptist & 4.92 & 4.72 & 4.24 & 4.08 & 4.08 \\
Reformed & 3.08 & 3.19 & 3.75 & 3.48 & 3.48 \\
Pentecostal & 4.08 & 3.95 & 4 & 4.08 & 4.13 \\
Presbyterian & 3.09 & 3.36 & 3.68 & 3.45 & 3.09 \\
Charismatic & 4.27 & 4.22 & 4.2 & 3.93 & 3.66 \\
\hline
\end{tabular}

(ii) Priority of Theological Institutions towards Spiritual Development

Students were asked to rate their institutions in terms of its priorities as they experienced them (with $1=$ lowest priority, and $5=$ highest priority). These priorities include pastoral ministry skills development, knowledge of the denomination/tradition, theological knowledge and competencies, growth in spiritual depth and moral integrity, and understanding of the social/cultural context. Table 4 show the means ${ }^{51}$ for each priority, which also shows that all students rated their institution higher in terms of the focus on spiritual development with the lowest mean from the Methodist (3.34) and Presbyterian (3.45) institutions.

\footnotetext{
${ }^{50}$ The means is for interpretation purposes, the non-parametric comparisons for each pair using the Wilcoxon method was used for analysis and groupings.

${ }_{51}$ The means of the different scale questions was calculated for interpretation purposes and not for analysis.
} 
Table 5. Chi-Square test for Spirituality as Institutional Priority

\begin{tabular}{|c|c|c|c|c|c|c|c|c|}
\hline & Methodist & Anglican & Baptist & Reform & Pentecostal & Presbyterian & Charismatic & \\
\hline Lowest & 7 & 6 & 0 & 6 & 2 & 5 & 3 & 29 \\
\hline Priority & & & & & & & & \\
\hline Neutral & 13 & 15 & 5 & 20 & 8 & 5 & 6 & 72 \\
\hline Highest & 18 & 23 & 20 & 26 & 30 & 12 & 36 & 165 \\
\hline Priority & & & & & & & & \\
\hline Total & 38 & 44 & 25 & 52 & 40 & 22 & 45 & 266 \\
\hline
\end{tabular}

To focus on the priority regarding spiritual development ("growth in spiritual depth and moral integrity"), chi-square tests were used to test if there was a significant association between spirituality and institutions. Table 5 shows that the proportion who chose the highest priority for spiritual development were the Baptist $(20 / 25=80 \%)$, Charismatic $(36 / 45=80 \%)$ and Pentecostal $(30 / 40=$ $75 \%)$. The other institutions showed spiritual development as a high priority with the following percentages: Methodist $(18 / 38=47 \%)$, Anglican $(23 / 44=$ $52 \%)$, Reformed $(26 / 52=50 \%)$ and Presbyterian $(12 / 22=55 \%)$. The probability value ( $\mathrm{p}$-value) is 0.0091 , which is smaller than 0.05 , which seems to indicate that a significant association exists between perceptions of priority of spiritual growth and theological institutions made at a 99\% level of confidence.

\section{(iii) Students' Satisfaction with Spiritual Development}

Students were asked to rate their satisfaction with their institution in terms of opportunities for spiritual growth, with $1=$ very satisfied and $4=$ not satisfied at all. A chi-square test was used to test if there is a significant association between satisfaction with spiritual development and institutions. The proportion of Charismatic $(42 / 45=95 \%)$ who chose "Satisfied," together with Baptist $(21 / 25=84 \%)$ and Methodist $(26 / 10=72 \%)$ institutions is high, while the Reformed $(28 / 24=53 \%)$ and Anglican $(23 / 21=52 \%)$ is low. In the Presbyterian institution the majority response was "Not Satisfied" $(14 / 22=64 \%)$ with the institutions' focus on spiritual development. The $\mathrm{p}$-value is 0.0001 which is smaller than 0.05 , which seems to indicate that a significant association exists between perceptions of priority of spiritual growth and theological institutions made at a 99\% level of confidence.

\section{(iv) Students' Perceptions on the Integration of Spirituality in Academic Courses} Students were asked to indicate the extent, from $1=$ never to $5=$ always, to what went on in class strengthened their spiritual life outside the classroom. A chi-square test was used to test for any significant association between 
integration and institution. The proportion of Charismatic $(42 / 45=93 \%)$, Pentecostal $(29 / 40=73 \%)$ and Baptist $(23 / 25=90 \%)$ institutions who chose "Often/Always" is higher than Reformed (23/52 = 44\%), Anglican (21/45 = $47 \%)$ and Presbyterian $(11 / 22=50 \%)$. The probability value ( $\mathrm{p}$-value) is 0.0001 which is smaller than 0.05 , which seems to indicate that a significant association exists between perceptions of priority of spiritual growth and theological institutions made at a 99\% level of confidence.

\section{(v) Students' Personal Spirituality}

Activities in personal spirituality showed that 247 (89\%) participants come from a Christian background, while 31 (11\%) did not. When students were asked how often they engage in different spiritual activities ( $1=$ daily to $5=$ not at all), the mean varied ( $\mu=1.45$ to $\mu=2.06$ ). Sixty-five per cent (182) of students felt that the workload at the theological institutions was adequate to sustain their personal spirituality, while 87 (34\%) did not agree with the statement. The main sources of stress during students' training were financial concerns (score of 3.42), issues with the institution (score of 3.27), integrating their learning with faith (score of 2.72), future job prospects (score of 2.66) and personal/family relationships (2.64).

\section{Discussion}

The goal of this study was to determine whether there was intentionality towards spiritual formation in theological institutions. The study results revealed that students perceived that institutions were intentional towards formational practices. In Figure 1, a histogram of the overall spiritual formation index shows that the majority of students agree or strongly agree with the spiritual formation index. Student perceptions in all six factors of the SFI (Table 2) showed that all institutions had low scores (showing higher agreement with spiritual formation). The most important dimension was "institutional commitment towards spiritual formation" which deals with questions about the intentional and strategic alignment of spiritual formation. The other five factors of the index are agents or methods that allow for formation to happen within the institution.

Institution commitment was evident most with the Charismatic and Pentecostal traditions, and this finding could be explained by the denominational emphasis on spiritual training. ${ }^{52}$ This finding was also supported by low scores in other factors like community life, staff involvement and formal and informal

52 Walter Hollenweger, Pentecostalism: Origins and Development Worldwide (Grand Rapids: Baker Academic Books, 1997), 79. 
learning which highlights an overall integrated learning environment. On the other end of the spectrum, the institutions with the highest scores (showing lower agreement with the spiritual formation) for all five factors were the Presbyterian and Reformed. Both denominations train in a university faculty and this formational mandate may clash with the focus of critical scholarship offered at universities. This finding highlights that a university setting presents more challenges in implementing a spiritual formational mandate. It would be difficult to seek to instil a specific habitus among theology students in a university classroom where similar ecclesial backgrounds or at least shared vocational trajectories cannot be assumed. The intention of spiritual formation may also be obscured by university accreditation demands, the compartmentalisation of theological disciplines and the marginalisation of spirituality in the life of the university. Previous studies show similar results. ${ }^{53}$

The results from the SFI also showed that all institutions had high scores for the second factor "services" which showed that there was a general lack of services offered that focused on supporting students in their spiritual growth. Greater priority should be given to services that assist students in psychological or emotional pain or experiencing life crises (e.g., divorce, death or loss of a loved one). Counselling services may be an essential component that needs to be evaluated and improved.

Three pertinent questions with regard to this study focused on students' perceptions of the institutions' priority regarding growth in spiritual depth and moral integrity, their satisfaction with their institution in terms of opportunities for spiritual growth, and whether what went on in class strengthened their spiritual life outside the classroom. In each of these questions significant differences between the proportions in student responses were evident. Charismatic, Baptist and Pentecostal institutions showed greater emphasis on spirituality as a priority and showed satisfaction with opportunities for spiritual growth and were spiritually strengthened by classroom activity. The institutions Methodist, Reformed, Anglican and Presbyterian found spirituality to be a high priority with a 50\% agreement with the statement, and in rating their satisfaction with opportunities for spiritual growth, Reformed and Anglican institutions showed $50 \%$ agreement, while student perceptions in the Presbyterian institution showed that $64 \%$ were not satisfied with the

53 Donald Macaskill, "Ministerial Training: Toolkits or Compasses? A Study of Training within the Church of Scotland," British Journal of Theological Education 11, no. 1 (2000): 24-34; Stella Ma, "The Christian College Experience and the Development of Spirituality among Students," Christian Higher Education 2 (2003): 321-339; Gary Wilton, "The Hind Report: Theological Education and Cross Sector Partnerships," Discourse: Teaching and Learning in Philosophical and Religious Studies 7, no. 1 (2007): 153-78. 
opportunities for spiritual growth. When asked whether what went on in class strengthened their spiritual life outside the classroom, students' perceptions in Reformed, Anglican and Presbyterian institutions showed a 40-50\% agreement with the statement, a significant percentage reported negatively under the never/seldom category for the same question: Reformed (30\%), Anglican (22\%) and Presbyterian (27\%) institutions. It may be worthwhile for institutions to assess their current courses to determine how they impact students in a holistic way.

What is evident from the subscription to the SFI (Table 3) is that even though students perceive the formation emphasis in their theological institution, this agreement is represented across a spectrum of agreement. From the results we can see the vocational model of the Charismatic and Pentecostal traditions on one end of the spectrum with lower scores and a greater commitment to different dimensions of the SFI. On the other end of the spectrum, we find the university models of the Reformed and Presbyterian institutions with higher scores and less commitment to the SFI. A plausible explanation for the differences is related to differences in the ethos and educational models used in each denominational institution. ${ }^{54}$ Eisner describes ethos as "a term that refers to the underlying deep structure of a culture, the values that animate it, that collectively constitute its way of life." ${ }^{55} \mathrm{He}$ views a sense of ethos as something that penetrates the surface symptoms and gets to the core values and shared vision of the school. One can view the institution's conceptual framework as a window to discerning a school's ethos and which helps shape the institution's curriculum and culture and has a lasting impact on students. ${ }^{56}$ Institutional structure can be seen as a factor that either hinders or promotes the integration of spirituality within the curricula and co-curricular on campuses. In infusing spirituality into campus life, it is important to note that nothing is value-free. When spiritual dimensions are excluded, the lack of incorporation of ethics, meaning and purpose into curricula and co-curricular efforts, then what is valued and not valued is communicated by default. Hence transformative efforts in the institutional culture begin within a holistic consideration of institutional values and purposes. Second, the way theological

54 David Guthrie has identified four varieties of institutional ethos that characterize approaches to Christian education and formation: rationalist, credentialist, maturationist and moralist, quoted from Harry Lee Poe, Christianity in the Academy (Grand Rapids: Baker Academic Books, 2004), 45.

55 Elliot Eisner, Perspectives 1: Ethos and Education (Dundee: Scottish Consultative Council on Curriculum, 1994), 12.

56 Dallas Blanchard. "Seminary Effects on Professional Role Orientations," RRelRes 22 (1981): 346-61; Jackson Carroll and Penny Marler, "Culture wars? Insights from Ethnographies of Two Protestant Seminaries,” Sociology of Religion 56 (1995):1-20. 
education is conducted represents different educational approaches to theology. Institutions involved in both academic and ministerial education may be operating with a variety of understandings as to what theology is and how it is learned. ${ }^{57}$ David Kelsey refers to these two models of education as ancient "Athens" and modern "Berlin." ${ }^{8}$ On the one side are areas of ministerial formation, an embodied reflective wisdom tradition which forms personality and character, relationship and leadership qualities, faith and spirituality and in which wisdom marries the pursuit of intellectual inquiry with the holiness of living. By contrast, academia emphasises the development of knowledge and cognitive skills (evaluative, analytical and critical skills) of the learner. Both of course take place within reflective traditions of inquiry: the former consciously and deliberately takes place from within an ecclesiastical theological tradition, which it questions, evaluates and challenges, and the latter from within its own philosophical and cultural tradition. Yet what distinguishes these practitioner and academic models of theology, at the opposite ends of a continuum of approaches to studying theology, are different ideas of how theology, learning and learner relate. ${ }^{59}$ Education for the ministry still holds a theology of learning that is not shaped by the competitive, individualised and marketorientated culture of higher education. In spite of developments towards a more holistic view of the individual learner, the dissonance between educational philosophy and theological understanding of the person and of formation would seem to suggest that higher education is not an ideal partner in learning for the ministry. ${ }^{60}$

Although all professions struggle to reduce the gap between what the "community of education" provides and what the "community of service" wants, closing this gap poses special problems for theological institutions. ${ }^{61}$ Not only are they expected to provide an education with intellectual integrity and practical applications, they are also expected to guard the faith. ${ }^{62}$ There is thus a

57 Paul Overend, "Education or Formation? The Issue of Personhood in Learning for Ministry," Journal of Adult Theological Education 4, no. 2 (2007): 133-48.

58 Kelsey, Between Athens and Berlin, 22

59 Gary Wilton conducted an empirical research project on six theological institutions (including theological and secular) to examine the approach to theological learning in each type in relation to the kind of formation envisaged. He concluded that whereas cooperation may be possible between institutions, structural partnerships are difficult because of divergent institutional aims (Wilton, "The Hind Report"), 153-78.

${ }^{60}$ Overend, "Education or Formation?" 146.

${ }^{61}$ Alister McGrath, A Passion for Truth: The Intellectual Coherence of Evangelicalism (Nottingham: Apollos, 1996), 17.

${ }^{62}$ Rhys Williams, "Organizational Change in Theological Schools: Dilemmas of Ideology and Resources," in Sacred Companies (ed. N. J. Demerath, P. Hall, T. Schmitt and R. Williams; New York: Oxford University, 1998). 
struggle between guarding the free inquiry and scientific objectivity revered by scholars, and protecting the beliefs and religious traditions valued by local churches.

What is also evident from this study is that even though there was agreement with the intentionality of spiritual formation in the SFI, when students were asked other correlating questions, some students did not agree with the formational emphasis. There could be many reasons for this inconsistency in student perceptions. A common one is that students chose to respond in a socially desirable way; questionnaires about attitudes and behaviours ask students to report typical behaviour and feelings as distinct from what they might perceive to be expected or desired. Being able to distinguish between religiosity and spirituality is a major consideration. What was also noted was the general apathy in the response to the questionnaire, which opens up the question whether students are resistant to formational advances. ${ }^{63}$ It is interesting to note that the majority of respondents in this sample are in the 18-28 age groups and fall into the Y-generation which represents a generation that is highly focused on grades and achievement, technologically advanced, prefers community participation and tends toward conformist thinking. ${ }^{64}$ Students seem to be more focused on what they want in a "consumer" sense and are looking for authentic experience with other people and God. There has to be sufficient substance, quality, hope and genuine concern and acceptance for them to fully engage in spiritual formation which institutions cannot always provide. ${ }^{65}$ Also students who are trying to prove themselves worthy within denominational assessment processes are careful in exposing those areas in their lives and faith that are in need of stretching and growth. The kind of vulnerability that lies at the base of Christian growth is the last thing that students feel free to show college or denominational authorities. More research is needed on the influences of post-modernity on formational initiatives. In fact, the degree to which spiritual formation programmes are effective in terms of enhancing ministerial identity and impact on the practice of ministry is yet to be determined. Theological institutions will have to find ways of tracking students beyond graduation to discover how their theological training has helped them and what actually sustains the graduates in their ministry.

In summary the findings show that there is a perceived intentionality towards spiritual formation at theological institutions, and this intentionality

${ }^{63}$ Merv Mercer, "Formational Initiatives at Wycliffe College," Theological Education 39, no. 2 (2003): 53-63.

${ }^{64}$ Sharon Parks, Big Questions, Worthy Dreams: Mentoring Young Adults in their Search for Meaning, Purpose and Faith (San Francisco: Jossey-Bass, 2000).

${ }_{65}$ Mercer, "Formation Initiatives at Wycliffe College," 55. 
is represented on a continuum. This finding is supported by the qualitative data analysis (which is not discussed in this article) in which a conceptual map was created showing "awareness," "awakening" and "being" as the descriptive lens through which to view formational initiatives at theological institutions. The findings showed that spiritual formation is at various stages of intention within institutions. "Awareness" was shown by a basic application of the spiritual formation and was most evident within the university-based models (Presbyterian and Reformed) where fragmentation exists with spiritual formation and is departmentalised and promoted on an ad-hoc basis at best. The concept "awakening" showed that institutions (Anglican, Baptist and Methodist) are moving towards a more deliberate intent to focus on real-life application while other institutions (Pentecostal, Charismatic) are showing deliberate intent, with focused programmes, community involvement and leadership support.

The second aim discussed in this article was the development of a valid and reliable instrument to measure the spiritual formation emphasis at theological institutions. The value of the Spiritual Formation Index is that it provides a way of evaluating formational efforts in a theological institution. It can serve as an assessment tool in providing an early warning about how students perform within the six dimensions of spiritual formation. In addition theological institutions and students may find it helpful to reflect on the items/dimensions, thus individual items in addition to subscale scores may have a heuristic value for students and institutions in the institutional setting. Although the Spiritual Formation Index was found to be valid and reliable it is seen as a rudimentary instrument and further research is needed to confirm the stability of results in other multiple samples which may provide critical information about validity, especially as it relates to the influence of social desirability on self-report responses. In terms of content validity, attending to the way words are used to describe spiritual practices is important as this may differ significantly between cultural groups, and therefore this instrument may misrepresent spirituality for respondents. Further research is needed to establish criterion validity and develop norms for different populations to allow for interpretations of individual profiles.

\section{Conclusion}

The spiritual maturity of future Christian leaders is an important challenge and needs to be addressed throughout the theological training. The most conducive setting for such education to take place is one which is intentional, collaborative and communitarian. As this study has showed identifying 
accurately the specific dimensions of spiritual formation and expectations of students' spirituality carries vital insights towards developing more integrated educational and nurturing environments for students' spirituality in theological education. As theological education in South Africa continues to assess its vision and goals within the changing landscape of higher education, this exploratory study offers evidence to support the assumption that theological institutions are promoting a formative approach to learning by fulfilling their stated goals in terms of shaping student spirituality.

\section{Bibliography}

Aleshire, Daniel. "ATS Profiles of Ministry Project." Pages 97-103 in Clergy Assessment and Career Development. Edited by R. Hunt, J. Hinkle and N. Malony. Abingdon: Nashville, 1990.

Amirtham, Samuel. "Spiritual Formation in Theological Education: An Invitation to Participate." Programme on Theological Education. Geneva: World Council of Churches, 1987.

Amirtham, Samuel and Robin P. Pryor, eds., Resources for Spiritual Formation in Theological Education. Geneva: World Council of Churches. 1989.

Astin, Alexander. What Matters in College: Four Critical Years Revisited. San Francisco: JosseyBass, 1993.

Babin, David et al. Voyage, Vision, Venture: A Report. Dayton: American Association of Theological Schools, 1972.

Ballard, Paul and John Pritchard. Practical Theology in Action: Christian Thinking in the Service of Church and Society. London: SPCK, 1996.

Banks, Robert. Revisioning Theological Education: Exploring a Missional Alternative to Current Models. Grand Rapids: Eerdmans, 1999.

Blanchard, Dallas. "Seminary Effects on Professional Role Orientations." RRelRes 22 (1981): 346-61.

Bollen, Kenneth. Structural Equations with Latent Variables. New York: Wiley, 1989.

Cannell, Linda. Theological Education Matters - Leadership Education for the Church. Newburgh: Edcot, 2006.

Carroll, Jackson and Penny Marler, "Culture Wars? Insights from Ethnographies of Two Protestant Seminaries." Sociology of Religion 56 (1995):1-20.

Comrey, Andrew. "Common Methodological Problems in Factor Analytic Studies." Journal of Consulting and Clinical Psychology 46 (1978): 648-59.

Cresswell, John, Vicki Clark, Michelle Gutmann and William Hanson. "An Expanded Typology for Classifying Mixed Methods Research into Designs." Pages 159-96 in The Mixed Methods Reader. Edited by V. Clark and J. Cresswell. Thousand Oaks: Sage, 2008.

Daloz, Laurent. Mentor: Guiding the Journey of Adult Learners. San Francisco: Jossey-Bass, 1999.

DeVellis, Robert. Scale Development: Theory and Applications. London: Sage, 2003.

De Vaus, David. Surveys in Social Research. London: ULC, 1991.

Edwards, Tilden. "Spiritual Formation in Theological Schools: Ferment and Challenge." Theological Education 17, no. 1 (1980): 4-10.

Eisner, Elliot. Perspectives 1: Ethos and Education. Dundee: Scottish Consultative Council on Curriculum, 1994.

Farley, Edward. Theologia: The Fragmentation and Unity of Theological Education. Philadelphia: Fortress, 1983. 
Finke, Roger and Kevin Dougherty. "The Effects of Professional Training: The Social and Religious Capital Acquired in Seminaries." Journal for the Scientific Study of Religion 41, no. 1 (2002): 103-20.

Foster, Charles; Lisa Dahill, Larry Golemon and Barbara Tolentino. Educating Clergy: Teaching Practices and Pastoral Imaginations. San Francisco: Jossey-Bass, 2006.

Gorsuch, Richard. "Measurement in Psychology of Religion Revisited." Journal of Psychology and Christianity 9, no. 2 (1990): 82-92.

Groome, Thomas. "A Religious Educator's Response." Pages 77-91 in The Education of the Practical Theologian: Response to Joseph Hough and John Cobb's Christian Identity and Theological Education. Edited by D. S. Browning, D. Polk and I. S. Evison. Atlanta: Scholars Press, 1989.

Harkness, Allan. "De-Schooling the Theological Seminary: An Appropriate Paradigm for Effective Ministerial Formation." Teaching Theology and Religion 4, no. 3 (2001): 141-54.

Hill, Phillip. "The Person of the Pastor: A Primer for Pastoral Effectiveness." Dissertation Abstracts International 63, no. 3 (2002): 992.

Hill, Peter and Ralph Hood, eds., Measures of Religiosity. Birmingham, Ala.: Religious Education, 1999

Hollenweger, Walter. Pentecostalism: Origins and Development Worldwide. Grand Rapids: Baker Academic Books, 1997.

Hough, Joseph and John Cobb. Christian Identity and Theological Education. Atlanta: Scholars Press, 1985.

Jones, Gregory. "Beliefs, Desires, Practices and The End of Theological Education." Pages 56-62 in Practicing Theology: Beliefs and Practices in Christian Life. Edited by M. Volf and D. Bass. Grand Rapids: Eerdmans, 2002.

Jones, Gregory and Kevin Armstrong. Resurrecting Excellence: Shaping Faithful Christian Ministry. Grand Rapids: Eerdmans, 2006.

Kelsey, David. Between Athens and Berlin: The Theological Education Debate. Grand Rapids: Eerdmans, 1993.

Lamoureux, Patricia. "An Integrated Approach to Theological Education." Theological Education 36, no. 1 (1999): 141-56.

Liefeld, Walter and Linda Cannell. "Spiritual Formation and Theological Education." Pages 239-52 in Alive to God: Studies in Spirituality. Edited by J. Packer, L. Wilkinson and J. Houston. Downers Grove: InterVarsity, 1992.

Lindner, John. "Ecumenical Formation: A Methodology for a Pluralistic Age." Theological Education 34 (1997): 7-14.

Lindbeck, George, Charles Wood and Tilden Edwards. "Spiritual Formation in Theological Schools: Ferment and Challenge." Theological Education 17, no. 1 (1980): 10-32.

Ma, Stella. "The Christian College Experience and the Development of Spirituality among Students." Christian Higher Education 2 (2003): 321-39.

Macaskill, Donald. "Ministerial Training: Toolkits or Compasses? A Study of Training within the Church of Scotland." British Journal of Theological Education 11, no. 1 (2000): 24-34.

Marshall, Joretta. "Formative Practices: Intent, Structure, and Content." Reflective Practice: Formation and Supervision in Ministry 29 (2009): 56-72.

MaGrath, Alister. A Passion for Truth: The Intellectual Coherence of Evangelicalism. Nottingham: Apollos, 1996.

Mercer, Merv. "Formational Initiatives at Wycliffe College." Theological Education 39, no. 2 (2003): 53-63.

Mills, Kathy. "The Culture of the Christian School." Journal of Education and Christian Belief7, no. 2 (2003): 129-42.

Naidoo, Marilyn. "An Investigation into Spiritual Formation Programmes at Selected Evangelical Institutions in Kwa-Zulu Natal.” D.Th. diss., University of Zululand, 2005. 
"The Call for Spiritual Formation in Protestant Theological Institutions in South Africa." Pages 129-42 in The Spirit that Empowers: Perspectives on Spirituality. Edited by P. G. R. de Villiers, C. E. T. Kourie and C. Lombaard. Acta Theologica Supplementum 11 (2008).

National Conference of Catholic Bishops. Program of Priestly Formation. 4th ed. Washington, D.C.: United States Catholic Conference, 1993.

O'Malley, John. "Spiritual Formation for Ministry: Some Roman Catholic Traditions - Their Past and Present." Pages 20-30 in Theological Education and Moral Formation. Edited by Richard Neuhaus. Grand Rapids, Eerdmans, 1992.

Overend, Paul. "Education or Formation? The Issue of Personhood in Learning for Ministry." Journal of Adult Theological Education 4/2 (2007) 133-48.

Pargament, Kenneth. "Of Means and Ends: Religion and the Search for Significance." International Journal for the Psychology of Religion 9, no. 1 (1992): 3-16.

Parks, Sharon. Big Questions, Worthy Dreams: Mentoring Young Adults in their Search for Meaning, Purpose and Faith. San Francisco: Jossey-Bass, 2000.

Percy, Martin. Shaping the Church: The Promise of Implicit Theology. Burlington: Ashgate, 2010.

Poe, Harry Lee. Christianity in the Academy. Grand Rapids: Baker Academic Books, 2004.

Poling, James and Donald Miller. Foundations for a Practical Theology of Ministry. Abingdon: Nashville, 1985.

Rice, Howard. The Pastor as Spiritual Guide. Nashville: Upper Room, 1998.

Schuth, Katrina. Seminaries, Theologates, and the Future of Church Ministry. Collegeville: Liturgical Press, 1999.

Stackhouse, Max. Apologia: Contextualisation, Globalisation and Mission in Theological Education. Grand Rapids: Eerdmans, 1988.

Steele, Les L. On the Way: A Practical Theology of Spiritual Formation. Grand Rapids: Baker, 1990. Strauss, Anselm and Juliet Corbin. Basics of Qualitative Research. Newbury Park: Sage, 1990.

Van der Ven, Johannes. Education for Reflective Ministry. Louvain: Peeters, 1998.

Ware, Corrine. Discover Your Spiritual Type: A Guide to Individual and Congregational Growth. Bethesda: Alban Institute, 1995.

Warford, Malcolm, ed., Practical Wisdom: On Theological Teaching and Learning. New York: Peter Lang, 2007.

Williams, Rhys. "Organizational Change in Theological Schools: Dilemmas of Ideology and Resources." Pages 208-25 in Sacred Companies. Edited by N. J. Demerath, P. Hall, T. Schmitt and R. Williams. New York: Oxford University, 1998.

Wilton, Gary. "The Hind Report: Theological Education and Cross Sector Partnerships." Discourse: Teaching and Learning in Philosophical and Religious Studies 7, no. 1 (2007): 15378.

Wood, Charles. Vision and Discernment: An Orientation in Theological Study. Atlanta: Scholars Press, 1985. 


\section{Appendix A}

\section{Spiritual Formation Index}

In your theological institution spiritual formation is evident in the following ways: mark one for each item ( 1 = Strongly Agree... 5 = Strongly Disagree $)$

\section{Institutional Commitment towards Spiritual Formation (Reliability: alpha $=83$ )}

a. You are aware of a formal spiritual formation programme that exists and that is part of your learning

b. There are staff member/s assigned to spiritual formation responsibilities

c. Confidentiality is maintained by those involved in spiritual formation

d. You are exposed to different ways of being spiritual

e. You are encouraged to live a balanced life in all areas: study, ministry, community life, recreation and spirituality

f. Your understanding of God is strengthened by classroom and campus experiences

2. Services offered by the institution (Reliability: alpha $=82$ )

a. Counselling is available to you as you go through various transitions and crises in your student life

b. The availability of mentors, spiritual directors and guides for students

c. Student interviews to monitor progress of your spiritual development

d. Annual goal setting and evaluation for each student

e. Psychometric and psychological testing is available for students

\section{Formal/informal learning (Reliability: alpha $\mathbf{8 5}$ )}

a. There are courses on spirituality, devotional theology, spiritual disciplines

b. Spirituality is integrated into the content of academic courses

c. Teaching methods that use different formal and informal learning experiences

d. On-going supervised in-service training/ministry in the local church

e. Fieldwork opportunities as a team into different ministry contexts

f. Availability of self-awareness activities e.g. workshops on personality, identity development, etc.

g. Appropriate bibliographical resources in the library and bookstore on spirituality

\section{Community life (Reliability: alpha $=80$ )}

a. A sense of community is nurtured at the institution and campus

b. Chapel and worship services for students and staff 
c. Recreational/ fun activities available as a community e.g. sports, picnics

$\mathrm{d}$. The ability of the whole community to pray and work together

e. The community exists within supportive campus relationships

5. Staff involvement in spiritual formation (Reliability: alpha $=89$ )

a. Caring, nurturing attitude of the staff towards students

b. Teaching staff are available for discussion or feedback on your work

c. Teaching staff practise and model principles of spiritual integrity

d. Teaching staff take interest in your personal welfare

e. Teaching staff assist you in your career decisions or issues of calling

6. Spiritual activities at campus (Reliability: alpha $=76$ )

a. Availability of retreats/prayer days for students

b. Reading of Scripture devotionally and spiritually

c. Service opportunities in the residential community dealing with social justice issues e.g. poverty 


\section{Appendix B}

Table 1. Rotated factor loadings

\begin{tabular}{|c|c|c|c|c|c|c|}
\hline Questions & Factor 1 & Factor 2 & Factor 3 & Factor 4 & Factor 5 & Factor 6 \\
\hline Q13_1A & 0.73 & 0.09 & 0.16 & 0.23 & 0.01 & 0.11 \\
\hline Q13_1B & 0.69 & 0.24 & 0.15 & 0.23 & 0.15 & 0.12 \\
\hline Q13_1C & 0.64 & 0.34 & 0.15 & 0.17 & 0.20 & 0.03 \\
\hline Q13_1D & 0.54 & 0.13 & 0.38 & -0.05 & 0.08 & 0.33 \\
\hline Q13_1E & 0.43 & 0.31 & 0.19 & -0.14 & 0.20 & 0.44 \\
\hline Q13_1F & 0.66 & 0.14 & 0.11 & 0.19 & 0.26 & 0.09 \\
\hline Q13_1G & 0.31 & 0.46 & -0.02 & 0.25 & 0.46 & 0.08 \\
\hline Q13_2A & 0.35 & 0.35 & 0.17 & 0.13 & 0.57 & -0.03 \\
\hline Q13_2B & 0.36 & 0.40 & 0.21 & 0.18 & 0.54 & 0.04 \\
\hline Q13_2C & 0.32 & 0.23 & 0.14 & 0.11 & 0.49 & 0.38 \\
\hline Q13_2D & 0.26 & 0.26 & 0.12 & 0.18 & 0.46 & 0.53 \\
\hline Q13_2E & -0.07 & 0.10 & 0.08 & 0.02 & 0.78 & 0.15 \\
\hline Q13_2F & 0.35 & 0.22 & 0.19 & 0.08 & 0.25 & 0.28 \\
\hline Q13_3A & 0.42 & 0.16 & 0.60 & 0.17 & -0.03 & 0.23 \\
\hline Q13_3B & 0.54 & 0.19 & 0.54 & 0.15 & -0.07 & 0.23 \\
\hline Q13_3C & 0.26 & 0.12 & 0.72 & 0.11 & 0.16 & 0.21 \\
\hline Q13_3D & 0.19 & 0.23 & 0.52 & 0.05 & 0.31 & 0.35 \\
\hline Q13_3E & 0.08 & 0.26 & 0.49 & 0.17 & 0.33 & 0.32 \\
\hline Q13_3F & 0.16 & 0.32 & 0.48 & 0.27 & 0.39 & 0.27 \\
\hline Q13_3G & 0.06 & 0.05 & 0.60 & 0.40 & 0.14 & -0.12 \\
\hline Q13_4A & 0.23 & 0.25 & 0.27 & 0.57 & 0.20 & 0.06 \\
\hline Q13_4B & 0.39 & 0.12 & 0.39 & 0.53 & -0.16 & 0.08 \\
\hline Q13_4C & -0.01 & 0.09 & 0.19 & 0.43 & 0.36 & 0.31 \\
\hline Q13_4D & 0.17 & 0.18 & 0.09 & 0.67 & 0.20 & 0.30 \\
\hline Q13_4E & 0.24 & 0.32 & 0.16 & 0.59 & 0.34 & 0.22 \\
\hline Q13_5A & 0.30 & 0.67 & 0.00 & 0.38 & 0.10 & 0.15 \\
\hline Q13_5B & 0.15 & 0.67 & 0.32 & 0.19 & 0.28 & -0.03 \\
\hline Q13_5C & 0.23 & 0.74 & 0.31 & 0.14 & 0.20 & 0.11 \\
\hline Q13_5D & 0.18 & 0.79 & 0.11 & 0.13 & 0.19 & 0.24 \\
\hline Q13_5E & 0.14 & 0.73 & 0.12 & 0.09 & 0.13 & 0.36 \\
\hline Q13_6A & 0.40 & 0.33 & 0.24 & 0.49 & -0.16 & 0.26 \\
\hline Q13_6B & 0.24 & 0.08 & 0.19 & 0.39 & 0.04 & 0.58 \\
\hline Q13_6C & 0.43 & 0.17 & 0.11 & 0.48 & -0.03 & 0.56 \\
\hline Q13_6D & 0.03 & 0.16 & 0.16 & 0.19 & 0.16 & 0.70 \\
\hline
\end{tabular}

